\title{
Home is Where the Heart is, but Where is "Home"?
}

\author{
Ines E. Vigil* \\ ${ }^{\star}$ Corresponding author: Ines E. Vigil; Email: estradavigil@arnet.com.ar
}

Received: January 12, 2022; Accepted: January 18, 2022; Published: January 25, 2022

Due to constant political and financial instability, many young adults are leaving Argentina moving to various places around the world searching for a more promising future. This emigration has been raising on and on for the last few years ...

For those of us who have been living abroad for some time, we know that living abroad is not easy and finding a new place to call home takes some time, one of the first questions you get when you meet someone is, where are you from? Of course, the answer to that question is easy. Later, when they get to know you, comes a second and sometimes tricky question, where is home for you.

\section{Where is Home for Me}

I was brought up in a family that moved from one country to another. Take into account that the internet and "family-based technology" are younger than me; so, staying connected was hard.... It was my dad's job. We all just followed the league. Every three or four years we would come back to "homeland" Argentina, but, for me, that was not home. No friends, no school, no known neighborhood... Home for me was where my parents lived, no special land, no matter the country, just that place where I could be myself. I was from "my family", that was when I discovered that for me home was where my heart was.

I grew up and discovered I had the "moving bee" inside. I just went on traveling and moving from one place to another. While I studied animal behavior, I saw that animals would try to take possession of the place they lived. Usually, they would mark it with their smell just to make it theirs. Make it home for them and their family. This way they could also let the rest know that place was theirs. Well, I guess humans, or at least me, do the same in some way. We decorate the places, do the lawn. We make it home.

\section{Attachment to Home}

There is a connection, a cognitive-emotional bond between us humans and our settings, this attachment to what we call home is a common human experience that is why moving isn't as easy as it might sound. To ignore this fact of minimizing its effects might make the emigration process harder.

It is no secret that people develop a strong attachment to what we call home. Nor related to a specific place, it is related to a sense of control, predictability stability.

\section{Home is Where My Heart is}

As I see a home as a part of my self-definition, I made a home of every place where every place I lived. I considered each of those places my home at one time or another, whether it was for months or years I made it mine. Home then was where I was, where my heart is. Me myself, that was my home.

So if you have decided to emigrate, if you chose to move to another country just remember to allow yourself the time to make that place you choose your home. This does not mean you regret what you left, it means your home is where your heart is.
Citation:

Vigil IE (2022) Home is Where the Heart is, but Where is "Home"? Psychol J Res Open Volume 4(1): 1-1. 